\title{
„A ziemia się jeszcze ruszała..." Masakra Żydów w Szczeglacinie w relacjach świadków
}

\begin{abstract}
Wstęp
W dolinie środkowego Bugu, na terenie gminy Korczew wciąż można usłyszeć niezwykle poruszające historie o ludziach i zdarzeniach z przeszłości. Historie, w których ważne miejsce zajmują prawosławni, Żydzi i Romowie, opowieści z obszaru wielokulturowego i wielowyznaniowego Podlasia, które odchodzą już, niestety, w zapomnienie wraz z ludźmi pamiętającymi wydarzenia sprzed wielu dziesiątków lat i ówczesny kształt życia.

Jednym $\mathrm{z}$ ważnych tematów, które powracają $\mathrm{w}$ rozmowach $\mathrm{z}$ tamtejszymi ludźmi, jest masakra kilkuset Żydów w obozie pracy założonym przez Niemców w Szczeglacinie leżącym nieopodal Korczewa. Jest to już właściwie ostatni moment, kiedy można jeszcze porozmawiać ze świadkami tych okrutnych wydarzeń. W miejscu, w którym naziści mordowali Żydów, dziś widać stertę „hrabiowskiej” słomy - Żydowizna, jak ochrzczono ten teren po wojnie, należy obecnie do spadkobierców hrabiów korczewskich. Żadnego znaku upamiętniającego mord nikt nie postawił, a młodsi mieszkańcy zazwyczaj nie są świadomi tego, że co dzień przechodzą obok miejsca straszliwej zbrodni.
\end{abstract}

\section{Obóz}

W Szczeglacinie mieścił się jeden z obozów pracy przymusowej dla Żydów, czyli, zgodnie z definicją Marty Janczewskiej, było to „odizolowane miejsce, do którego robotnicy byli dowożeni na czas wykonywania określonych zadań, a po ich wykonaniu zwalniani lub mordowani (w zależności od etapu Zagłady)"1.

Żydowscy robotnicy ze szczeglacińskiego obozu zostali wymordowani wraz z rodzinami, a sposób ich zabijania można byłoby określić jako specyficzne połączenie najczystszego nazistowskiego wyrachowania i pierwotnego, prymitywnego bestialstwa. Otóż perfidia Niemców polegała na takiej organizacji mordu, że właś-

${ }^{1}$ M. Janczewska, Obozy pracy przymusowej dla Żydów na terenie dystryktu warszawskiego [w:] Prowincja noc. Życie i zagłada Żydów w dystrykcie warszawskim 1939-1945; red. B. Engelking, J. Leociak, D. Libionka, Warszawa 2007. 


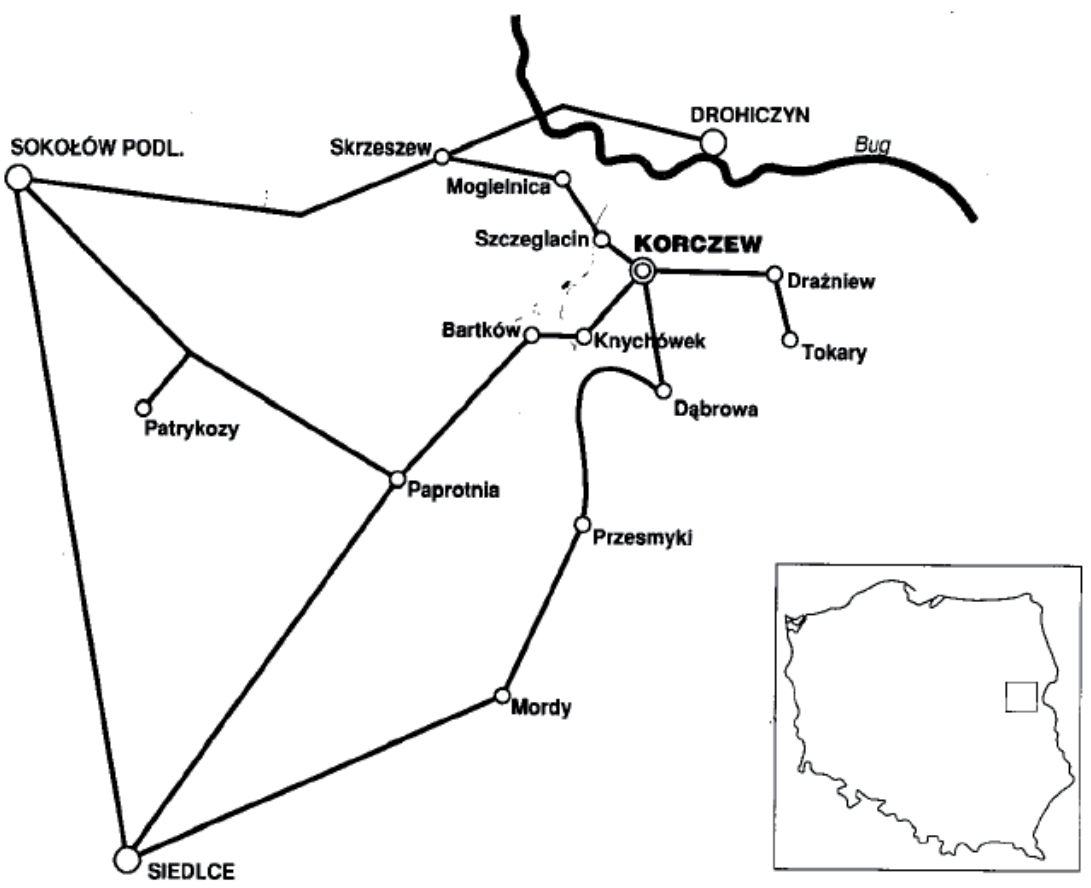

Rys. 1. Położenie Korczewa

(za: Adam Buszko, Ziemia korczewska, Korczew 1997).

ciwie to sami Żydzi wykonali niemal wszystkie czynności z nim związane, z wyłączeniem samego aktu zabijania. Według niektórych relacji Żydzi sami kopali sobie groby, ufając, że są to doły do przechowywania ziemniaków na zimę, to żydowscy robotnicy byli grabarzami własnych żon i dzieci, by za chwilę zostać przysypanymi ziemią przez policjantów żydowskich w dołach śmierci.

Perfidia nazistów polegała również na tym, że cała akcja została przeprowadzona bardzo szybko i „po cichu”, najprawdopodobniej rankiem 22 października 1942 r. Niemcy przyjechali wówczas samochodami do obozu, dokonali jego likwidacji, przejechali po wypełnionych ciałami Żydów dołach seriami kul z karabinów maszynowych, zasypali doły wapnem, przykryli je ziemią i niezwłocznie oddalili się w kierunku Drohiczyna. „Na wiosnę”, jak mówią świadkowie, zapewne w 1944 r., powrócili na to miejsce, by dokonać ekshumacji szczątków w celu ostatecznego zatarcia śladów.

W kontekście tego cynicznego wyrachowania zbrodniarzy zadziwia prymitywizm samego narzędzia mordu - drewnianej pałki. Niemcy przecież raczej nie zabijali ciosami pałek, prędzej rozstrzeliwali (lub np. palili żywcem w stodołach). Może więc najbardziej prawdopodobna jest wersja wydarzeń mówiąca o tym, że Żydów tłukli pałkami ukraińscy esesmani w niemieckich czapkach. Niektórzy Ży- 
dzi mieli sami skakać wcześniej do dołu, by uniknąć ciosów, gdyż stojący po obu stronach naziści „na przemian młócili”2 nadchodzących.

Praca Żydów, którzy zginęli w tym obozie, związana była z gospodarką wodną i polegała na melioracji użytków rolnych i regulacji rzeki Kołodziejki. Pracowali oni w skrajnie trudnych warunkach, często przez całe dnie w wodach rzeki, co prowadziło między innymi do puchliny nóg. Ciągłe niedożywienie, a także szerzące się choroby wycieńczyły śmiertelnie wielu spośród nich.

Początkowo obóz mieścił się w Cerkwisku nieopodal Bartkowa Nowego, a wraz z posuwaniem się robót wzdłuż rzeki został przeniesiony do Szczeglacina. Żydzi, którzy zostali ulokowani w Szczeglacinie, pochodzili z różnych miejscowości. We wrześniu 1941 r. przebywało tam 150 robotników, w tym 85 z getta w Sokołowie. Arbeitsamty, niemieckie urzędy pracy, nakazywały Judenratom, aby wyznaczały do obozu określoną liczbę mężczyzn. Wśród bogatszych Żydów powszechny był proceder wykupywania się w Judenracie od skierowania do obozu. Sytuacja odwróciła się na jakiś czas w okresie likwidacji gett, kiedy to obozy pracy jawić się mogły jako dające nadzieję na ocalenie. Po likwidacji getta w Sokołowie 22 września $1942 \mathrm{r}$. w Szczeglacinie nadal pracowało kilkuset (według różnych relacji od 400 do 800) Żydów.

\section{„Jak zaleciałem, to ziemia się jeszcze ruszała”3}

Mój dziadek Ludwik Woźniak jest mieszkańcem należącej do gminy Korczew wsi Bartków Stary. Jego świadectwo dotyczące mordu w Szczeglacinie ma niezwykłą wagę - jako dwunastoletni chłopiec był naocznym świadkiem tych wydarzeń. Dotychczas opowiadał mi z dużą swobodą różne historie, w tym tę o szczeglacińskich Żydach. W momencie jednak, gdy wyciągnęłam dyktafon, by nagrać opowieść, a później przedstawić ją na piśmie, dziadek na chwilę zaniemówił. Myślę, że zastanawiał się, jak swoje doświadczenia ubrać w słowa, gdyż czuł, że jego opowieść jest bardzo ważna, jest jedyna. Że widział i wie, jako jeden z nielicznych. Miał świadomość wyjątkowości swego statusu, tego, że był świadkiem wyjątkowej zbrodni dokonanej na ludziach, którzy byli jednocześnie Innymi.

Ludwik Woźniak: „Byłem u siostry Ireny w Szczeglacinie i nagle usłyszałem szum, że przyjechali Niemcy i biją Żydów. Mordują, zabijają Żydów. Więc zrobiła się we wsi panika, no bo tak było, rozbój, że Żydów biją. I ja z ciekawości poszedłem tam na to miejsce, gdzie biją Żydów, ale że nie można było wejść na ten plac, gdzie mordowali, to była stodoła Stanisława Kosmali, zaraz przy rzeczce, i wszedłem do tej stodoły. W tej stodole ktoś jeszcze siedział ze mną, tak mi się zdaje. A że tam deski rzadko były poprzybijane, to ja przez szpary wszystko widziałem, a odległość była około pięćdziesiąt metrów.

${ }^{2}$ Określenie zaczerpnięte z relacji świadka L. Woźniaka, Bartków Stary, gmina Korczew, ur. 1930, rozmowa z autorką z dn. 4 VIII 2009 r.

${ }^{3}$ L. Woźniak, rozmowa z autorką z dn. 4 VIII 2009 r. 
Stały baraki, prawdopodobnie dwa baraki i od baraków jakieś około trzydzieści metrów były wykopane dwa okrągłe, głębokie doły. I te Żydy szły gęsiego jeden za drugim w odległości około jednego metra do tych dołów, z baraków. A przy dole stał Niemiec z taką, o, pałką, a z drugiej strony drugi. Takie pale mieli w rękach, $z$ jednej strony cieńsze, a z drugiej grubsze. Jak Żyd dochodził, to on buch! w łeb go tą pałką i on w dół wpadał. Jak ten pałkę podnosił do góry, to w tym czasie drugi buch! I tak na przemian młócili. Buch! buch! i do dołu, i do dołu.

Nawet tak było, że niektóry żywcem skoczył w ten dół. Żeby choć nie dostać, skoczyć w ten dół, bo wiedział, że pałką w łeb dostanie. I żywcem nawet skakali. Jak już wszystkich wybili, jeden, drugi dół, to posypali czymś białym; widziałem, jak to się kurzyło, wznosiło się do góry. Nie wiem, czy to był chlor, czy to było wapno. A nie, najpierw maszynowym karabinem po tych dołach pojeździł i tym białym czymś zsypali i zawalili ziemią. Bardzo szybko to robili i w samochody, i pojechali w stronę Drohiczyna. A ja z tej stodoły wybiegłem i poleciałem tam na miejsce, że tam może jeszcze coś znajdę po tych Żydach. Jako dziecięcy umysł, zobaczę, co tam jeszcze słychać, czy żywi jeszcze...

Jak zaleciałem, to ziemia się jeszcze ruszała. A tam były różne szmaty śmierdzące pożydowskie, to czapka leżała, to przewrócony kawałek stołka... To trochę pieniędzy, tych papierów, ale porwane, poskubane, rzucone.

I wsiedli w samochody i pojechali, i tak się skończyło.

A mówił mi kolega Ciura ze Szczeglacina, który się u nas ożenił i przyszedł do naszej wioski w przystępy ${ }^{4}$, że siedzieli w kilkoro w domu i wieczorem dwóch Żydów przyszło z tych dołów. Kulą nie trafione byli. A że żywcem skakali, to mógł już nie dostać, no i ta ziemia się ruszała... Oni mogli już później umrzeć... Mój kolega mówił, że dwóch wyszło z tych dołów i wieczorem przyszli. Światło się paliło i przyszli, posiedzieli, ale każden się bał i w nocy gdzieś poszli w nieznane. Tyle ja wiem.

Wśród mordowanych byli mężczyźni, kobiety i dzieci, były tam całe rodziny, nie tylko ci sprawni do pracy. Dobrze pamiętam.

Tu, z tą rzeką, to choćbym żył pięćset lat, to i tak bym wiedział! Wszystko pamiętam, wiem, jak było. A o tym kto się dowiedział, ten się dowiedział po wsiach...”

Zapytałam, czy to przeżycie sprzed ponad sześćdziesięciu lat tak silnie zapadło mu w pamięć dlatego, że było tak straszne.

„Nie, ja... o przeżyciu... to nic mnie nie wzruszało, cholera, ja wiem... Tylko że wielkie widowisko, jakby się to $\mathrm{w}$ telewizorze działo. Ale żeby mnie tak dreszcz, jakieś przerażenie czy współczucie, to nie. Takie: o! Żydów biją - niezwykłe wydarzenie. Przecież dzieciak tym bardziej powinien się bać, a ja nic. Toć jak poleciałem zaraz tam, to się nie bałem".

Ciekawiło mnie ponadto, czy Żydzi, idąc kolejno ku dołowi i wiedząc już przecież, co ich czeka, próbowali uciekać, czy stawiali jakiś opór. „Mordowani pokornie

\footnotetext{
${ }^{4}$ Regionalizm: w przystępy przychodzi mężczyzna, który po ślubie „przystępuje” do rodziny żony i u niej zamieszkuje.
} 
szli do dołów, nie uciekali. Jak gęsie się zagania”. Świadek dziwi się temu: „O nie, Szwabie, ja bym kopał dół, a ty byś mnie...?!".

\section{Ze środka piekła}

Istnieje też inna relacja naocznego świadka tamtej masakry. Tym razem jest to opis okrutnych wydarzeń oglądanych, do pewnego momentu, niejako od środka. 31-letni wówczas mieszkaniec Szczeglacina - Piotr Szczepaniak - znalazł się akurat tego dnia wewnątrz „getta”, jak nazywa, podobnie jak moi rozmówcy, tamtejszy obóz pracy. Niestety świadek już nie żyje, dlatego muszę poprzestać w tym przypadku na relacji spisanej piętnaście lat temu przez Zbigniewa Chybowskiego - lokalnego historyka, emerytowanego nauczyciela historii w korczewskiej szkole.

Piotr Szczepaniak: „W przeddzień likwidacji getta w Szczeglacinie przyszedł do mnie policjant żydowski i wynajął mnie z furmanką. Następnego dnia z samego rana miałem zawieźć pod Sokołów jedną rodzinę żydowską (około pięć osób). Miałem stawić się w getcie, gdy będzie szarzało. Bardzo wcześnie rano wjechałem na teren getta furmanką. Rodzina żydowska, którą miałem wieźć, zaczęła się pomału gramolić, szczególnie dzieci opóźniały wyjazd. Podczas tego krótkotrwałego zamieszania getto zostało otoczone. Niemcy kazali mężczyznom kopać doły. Jako że byłem na terenie getta, złapali i mnie. Starałem się wytłumaczyć, że jestem Polakiem, ale nikt mnie nie rozumiał. W tym czasie pojawił się Dropia, mieszkaniec Szczeglacina, który po niemiecku zaczął tłumaczyć Niemcom, że ja jestem Polakiem, że tylko wjechałem na teren getta, by podwieźć narzędzia potrzebne Żydom do prac przy regulacji rzeki Kołodziejki. Po długich staraniach udało się przekonać Niemca, że rzeczywiście jestem Polakiem, dzięki temu wypuścili mnie.

Później pobiegłem oglądać to, co działo się w getcie. Najbliżej getta stał dom Mieczysława Solicha. Z tego domu widziałem wszystko. Najpierw mężczyźni kopali doły, później Niemcy przyprowadzili nad te doły kobiety i dzieci i kazali im skakać, a jako że nie chcieli skakać, uderzali je długimi pałami. Niektóre z nich, chcąc uniknąć ciosów, skakały do tego dołu »dobrowolnie«. Gdy dół był już pełny, któryś z Niemców podszedł do niego z karabinem maszynowym i pociągnął serią. Zaraz potem w dole uspokoiło się. Następnie mężczyźni zasypywali swoje żony i dzieci.

Zaraz potem musieli kopać doły dla siebie samych i jeden nieduży dodatkowo. Gdy doły były już gotowe, kazano podejść do nich mężczyznom i wszystko powtórzyło się dokładnie tak samo. Właściwie była różnica, ponieważ tym razem grabarzami byli policjanci żydowscy. Gdy doły zostały już zawalone, przyszła kolej na policjantów. Kazano im podejść do dołów i sytuacja się powtórzyła! Policjantów przysypali będący na służbie u Niemców Ukraińcy. Wkrótce potem oddziały niemieckie odjechały, bo było po wszystkim. Wszystkie zabudowania getta zostały. Niektórzy ludzie, w tym także ja, chodzili szukać złota.

Pamiętam, że któregoś dnia, a właściwie w nocy, poszliśmy do getta. Szukając po ciemku, natrafiłem na jakąś klapę. Gdy ją otworzyłem, okazało się, że był tam 
schowek. Wszedłem tam i macałem dalej i... natrafiłem na... portmonetkę z biżuterią. To był mój cały łup! Wkrótce potem getto spłonęło. Cale getto było otoczone drutami kolczastymi, które sięgały na wysokość około 2,5-3 m. Znajdowało się tam chyba pięć budynków. Jeden budynek stał poza drutami i był to budynek, w którym mieszkali policjanci żydowscy. Inne budynki stały już za drutami (chyba cztery). Nie przypominam sobie, by była tam jakaś kuchnia, wydaje mi się, że Żydzi gotowali sobie na różnych trójnogach i w garnkach, na placu.

W samym Szczeglacinie mieszkały przed wojną trzy rodziny żydowskie”5.

\section{Relacja Kosmali}

W stodole ojca Tomasza Kosmali Ludwik Woźniak ukrył się jesienią 1942 roku, żeby przyglądać się masakrze Żydów. Jak wspomniałam we wstępie, w miejscu, w którym był obóz pracy, nie ma dziś śladu po tamtych wydarzeniach. Snopki słomy przykrywają, niczym zasłona niepamięci, krwawy fragment dziejów tej ziemi.

Tomasz Kosmala mówi między innymi o ocalonych z masakry, których widział lub o których słyszał ${ }^{6}$ : „Były dwie Żydóweczki, wystraszone, widziałem, gdzieś się schowały, i jeden Żydeczek został i po wsi chodził. Bolciowa Kiryluczka [w chwili składania tej relacji już nie żyła - M. W.] dawała mu jeść, ale tylko kilka dni, bo strach, zaraz kulą w łeb. Dwóch gdzieś wyszło, nie byli w tym czasie w getcie, przeżyli. Jeden to doktora syn i drugi, przystojny, młody chłopak. Jak do wojska potem brali, to po wojskowemu był ubrany. Ze mną stał, rozmawiał. Co tam, Tomek? - pytał. - Udało się - mówił.

Były takie trzy siostry, Estera, ta najmłodsza, przyszła do nas, płakała: Aj waj, Kosmalowa! Matka jej dała jeść, posiedziała i poszła gdzieś. Tak było, jakby ona została, toby nam rodzinę całą wybili. A gdzie ona dalej poszła? Może do Sokołowa? Do Treblinki? Kula w łeb, jak ukrywać, strach, że sąsiad doniesie... Nie wiadomo, co z nimi dalej, toż jak oni zobaczyli tę rzeź, to jak najdalej uciekali”.

Dołożył również do zarysowującego się obrazu wydarzeń nowe informacje: „Polak, D., ich pilnował, tych Żydów w getcie, takie miał żółte buty. A później, jak kapitulacja była, to on uciekł na Zachód, bo się Niemcom wysługiwał i może by go zabili.

W obozie może z 500 osób Niemcy zabili. Jak wcześniej kazali im kopać te doły, to mówili, że to na ziemniaki dla nich, przed zimą, i Żydzi myśleli, że na kartofle. Myśleli, że będą zimować. A to było dla nich samych.

A później, na wiosnę, przyjechali Niemcy wybierać kości, rozkopali te doły, cały samochód załadowali, wystawały ręce - mięsa nie było, tylko sama czerwona kość. Jeszcze jak z Rosją wojowali. Zacierali ślady. Może do Treblinki, ich spalić...”.

${ }^{5}$ P. Szczepaniak, Szczeglacin, gmina Korczew, ur. 1911, zapis opowieści sporządzony dn. 3 VII 1994 r. przez Z. Chybowskiego.

${ }^{6}$ T. Kosmala, Szczeglacin, gmina Korczew, ur. 1924, rozmowa z autorką z dn. 4 VIII 2009 r. 


\section{„A przyszedł Hitler złoty”}

Dlaczego Niemcy postanowili uregulować krętą, zmierzającą w stronę odległego o kilka kilometrów Bugu rzekę, czy raczej rzeczkę, Kołodziejkę? W tym celu przecież założyli obóz pracy dla Żydów. Jeden z najstarszych mieszkańców Bartkowa Nowego Mieczysław Wasiluk roztoczył w tym kontekście wizję włości, które z czasem miały stać się własnością niemieckiego oficera. Prace regulacyjno-melioracyjne, do których zmuszano Żydów, miały między innymi służyć osuszeniu nadrzecznych terenów przeznaczonych dla ich przyszłego (i niedoszłego) właściciela. Relacja Wasiluka przybliżyła nieco obraz pracy Żydów przy regulacji rzeki:

„Najpierw getto było przy Cerkwisku.

Była taka historia - Leosin [przedwojenny mały folwark w majątku korczewskim, położony tuż nad rzeką - M. W.] był przydzielony niemieckiemu oficerowi. Podczas wojny Niemców z Sowietami w 1941 r. Niemcowi już szykowali tutaj siedzibę. Regulowali rzekę, w Bartkowie od mostu hrabiowskiego zaczęli. Jak wojna się skończy, to on miał tu przyjść gospodarzyć, na Leosinie się miał usadowić. Żydom baraki zrobili i tu mu wszystko regulowali. Żydzi chodzili kopać na bosaka, w czwórkach, niekiedy przedstawiciel ich prowadzał i... śpiew:

Marszałek Śmigły Rydz nie nauczył nas roboty nic,

A przyszedł Hitler złoty, nauczył nas roboty...

Zakasani byli po kolana i na bosaka kopali te rzeki. Jak dokopali już do bartkowskiej granicy Leosina, to im daleko było chodzić, bo oni regulowali aż do Buga, i te baraki przenieśli za Szczeglacin. Oni tam pracowali, aż skończyli tę robotę. I zrobili im masakrę, rozstrzelali. Kazali im rowy wykopać i postawili nad rowami, i maszynowym karabinem...

A nie, nie tak było! Postawili dziesiętników z nich i dali pałki, i pałkami w głowę, i wpadali w doły. Mordowali swoich dziesiętnicy wybrani. Który nie chciał pałką dostać, to sam skakał do tego rowu, drugi na niego. A na ostatku tych, co ich bili, rozstrzelali i wrzucili.

A później zawołali szczeglacińskich ludzi, by przykryli, to ci ludzie mówią, że się ziemia ruszała. A dużo osób ze Szczeglacina z okien widziało, to opowiadają, tam jeszcze są tacy, co opowiadają...”.

To zupełnie inny obraz masakry w Szczeglacinie niż ten przedstawiany przez jej obserwatorów, Woźniaka i Szczepaniaka. Najpewniej wieść o mordzie, niosąc się po wsiach, uległa zniekształceniom przez te wszystkie lata dzielące nas od czasu zbrodni. Wasiluk jako mieszkaniec Bartkowa wie dużo więcej, i prawdopodobnie jest tu bliższy historycznej prawdy, o wcześniejszym miejscu stacjonowania Żydów, czyli obozie pracy w Cerkwisku, a także wykonywanych tam przez nich pracach. O likwidacji obozu pracy w Szczeglacinie słyszał jedynie z drugich ust. Mit szczeglacińskiego mordu, który przedstawił, niesie ze sobą znaczenia przydawane im przez

${ }^{7}$ M. Wasiluk, Bartków Nowy, gmina Korczew, ur. 1928., rozmowa z autorką z dn. 3 VIII $2009 \mathrm{r}$. 
mieszkańców. Dlaczego to żydowscy „dziesiętnicy” mieliby mordować pozostałych, dlaczego Niemcy mieliby dawać narzędzie mordu Żydów w ich własne ręce?

Relacje świadków, takich jak Woźniak czy Szczepaniak, którzy zdecydowanie twierdzą, że pałowali esesmani w niemieckich czapkach, najpewniej Ukraińcy, raczej rozwiewają wątpliwości faktograficzne. Ponadto z ich relacji wynika, że Niemcy chcieli całą sprawę załatwić szybko i „po cichu” - zaraz do dokonaniu masakry odjechali „taksówkami” (takim mianem powszechnie określano wtedy samochody osobowe). A więc nie jest prawdopodobne, że „zawołali szczeglacińskich ludzi, by przykryli" doły z ofiarami mordu (przy tym, co ważne i co wielu podkreśla, kilka osób przeżyło egzekucję, o czym miała świadczyć ruszająca się ziemia).

Wasilukowi bliższe są wydarzenia w Cerkwisku: „W Cerkwisku spośród Żydów tylko mężczyźni byli. Siedmiu Żydów tu zmarło. A w międzyczasie sprowadzili tu stu Ruskich, by chodzili co dzień do roboty na paśnie. Dwóch Niemców ich ganiało do buraków, kopania kartofli. Wracając, pod pachą każdy niósł buraka i później na placu było widać: ognisko palili i sobie piekli, jedli. Straszna ich śmiertelność, dezynteria wzięła, dziewięćdziesięciu pochowali tam, a siedmiu tylko Żydów w czasie robót zmarło. Kopany był rów coraz dalej i co raz dalej przesypywany był. Niby później zrobili ekshumację, ale tylko dziurę zrobili. Tam, gdzie łąka Woźniaków, teraz tylko znać dołek. Była tablica, nazwiska wypisane, po wojnie zaginęła. Aj, trzeba było wziąć, przechować, by była pamiątka...”.

Wasiluk jest pewien, że po wojnie była na łące pod lasem tabliczka z nazwiskami zmarłych, i żałuje, że jej nie przechował, że zaginęła. Ciekawe, kto taką tablicę kazał postawić i w jaki sposób zniknęła...

Sama praca przy regulacji Kołodziejki wedle Wasiluka wyglądała następująco: „Bili pale, płotki, faszyną i darniną okładali boki. Bo Niemcy to gospodarni. Szykowali dla nowego pana. Bo to była rzeka kręcona wkoło, Kołodziejka, wylewała. Ale nazwa prawdopodobnie od kołodzieja jakiegoś. Regulowali od mostu w Bartkowie do Buga. My byliśmy łebki młode, czasem ktoś poleciał nad rzekę ryb nałapać koszykiem, i widzieliśmy, jak regulowali.

W Cerkwisku, od Kołodziejki ze dwieście metrów, stały dwa baraki czy trzy, był rów i z dwóch stron kolczaste druty na dwa metry. I brama była, barak ze służbą, ochroniarze. A jak za Szczeglacin Żydów zawieźli, to tu wszystko rozebrali, zrównali, że byś nie poznał"9.

Na pytanie, czy byli wśród miejscowych ludzi tacy, którzy starali się udzielić pomocy Żydom, na przykład podrzucić im coś do jedzenia, Wasiluk stwierdza kategorycznie, że to nie było możliwe. „Baraki były ogrodzone, a do roboty szli pod niemiecką eskortą. Raz, jak Ruskich gnali do roboty, a ja wiozłem rzepę i ich mijałem, oni ręce wyciągali, to ja im tej rzepy rzuciłem. Niemiec doleciał, jak kolbą dał, tom tylko fiknął, a konia batem!”10.

\footnotetext{
${ }^{8}$ Ibidem.

${ }^{9}$ Ibidem.

${ }^{10}$ Ibidem.
} 
Wasiluk nie wie, ilu było Żydów, ale pamięta, że „to nie miejscowi, przywiezieni skądś, może z Siedlec...”. Po czym podsumowuje, niestety, zgodnie z prawdą: „Teraz ludzie nawet nie wiedzą, gdzie tamci byli chowani. A ja wiem. Teraz śladu nie ma, czyściutki plac zostawili”11.

\section{Zwierzyna łowna - Josek Kopyto}

W Archiwum Żydowskiego Instytutu Historycznego jest jedna relacja, w której wzmiankowana jest miejscowość Szczeglacin. Jest to zeznanie Joska Kopyto sporządzone w 1947 roku. Dotyczy ono także innych miejscowości w tym rejonie, szczególnie Sokołowa Podlaskiego, w którym Kopyto żył, również w latach okupacji. Josek Kopyto urodził się w 1897 r. W swoim obszernym zeznaniu opisuje lata okupacji spędzone w getcie w Sokołowie oraz w okolicznych miejscowościach, starając się wskazać pomocnych ludzi zarówno wśród Polaków, jak i Żydów, a nawet „dobrych Niemców”, którzy mu pomogli przeżyć Zagładę; wzmiankuje także liczne ciemne typy.

W świetle relacji Kopyty: „W 1941 roku został założony obóz w Szczeglacinie, 20 km od Sokołowa Podlaskiego. W obozie było kilkaset ludzi. W Sokołowie wyznaczono, kto ma iść do pracy. Bogaci nie szli, wykupywali się przed Judenratem. Judenrat wyznaczył, kto ma ile dać miesięcznie za niepójście do tej pracy. Aprowizacja niemiecka wyznaczyła dla robotników w tym obozie chleb. Robotnicy osuszali błota w majątku. Racja, którą Niemcy przyznawali, składała się z 1,5 kg chleba. Komendantami obozu byli Rubin Rozenberg, Dawid Liberman, przed wojną zwykli ludzie. Judenrat brał miesięcznie 35 kwintali mąki, ale i to nie starczyło. Z początku Judenrat dawał każdemu robotnikowi po $1 \mathrm{~kg}$ chleba, pobierając większe sumy od tych, co nie szli do pracy. Ale tak było tylko w pierwszych czasach. Później robotnicy nie dostawali nawet $20 \mathrm{dkg}$ chleba, resztę Judenrat brał dla siebie. Judenrat otrzymywał dla pracowników cukier, tłuszcz i marmeladę. Zrobili sobie ładny sklepik na żydowskich nieszczęściach ${ }^{12}$. [...]

Mój były wspólnik Rubin Rozenberg [z lektury zeznania możemy wnioskować, że Kopyto był przed wojną bogatym kupcem, mającym rozległe kontakty wśród Żydów i Polaków - M. W.] był w obozie pracy w Szczeglacinie. Było tam jeszcze 800 Żydów. Pracowali dalej po likwidacji Sokołowa [chodzi o likwidację getta w Sokołowie 22 września 1942 r., podczas której mordowano lub wywożono Żydów do Treblinki - M. W.]. Może się łudzili nadzieją, że przetrwają. Mój wspólnik Rubin Rozenberg stracił przy likwidacji Sokołowa swego jedynego brata z synem jego. Rubin Rozenberg, myśląc, że może mnie uratuje, przysłał mi przez jednego Polaka Władysława list, w którym mi proponował, bym się przeniósł do obozu pracy w Szczeglacinie. List ten brzmiał następująco: »Kochany bracie, straciłem brata,

\section{${ }^{11}$ Ibidem.}

${ }^{12}$ AŻIH, 301/4085, Josek Kopyto, Przeżycia w Sokołowie Podlaskim i okolicach, 24 III 1947, s. 13,14 . 
przyjmuję ciebie na jego miejsce jako kochającego brata. Po przeczytaniu tego listu nie płacz, żeby się wrogowie nie dowiedzieli. Przyszykowałem dla ciebie miejsce w obozie. Powiedz, kiedy przysłać po ciebie, to przyślę«. Przeczytałem żonie ten list. Rozpłakaliśmy się oboje, lecz żona moja powiedziała, że nie pójdziemy do obozu. Odpisałem mu: »Żyj nadzieją, bracie. Nasza krzywda nie będzie darowana, nasza krew nie darmo się leje, nie płacz«. Po przesłaniu tego listu przez tego samego Polaka otrzymałem przez tegoż znak od Rubina, że list mój otrzymał ${ }^{13}$. [...]

Mój przyjaciel Pinches Jankiew Lewin nie wiedział, co robić. Pytał się mnie: co będzie dalej? Mówiłem: ratujcie się, jak kto może. Lewin poszedł do obozu pracy w Szczeglacinie, gdzie miał syna. Wkrótce potem obóz w Szczeglacinie został zlikwidowany i wszyscy Żydzi, którzy tam byli, zginęli ${ }^{14}$. [...]

Około 22 października 1942 r. dostałem list od Rubina Rozenberga z obozu w Szczeglacinie, w którym zapytywał, jakie mam zamiary. Odpowiedziałem mu listownie, że jeżeli mi się uda gdzieś ukryć, to przyślę po niego. List ten odesłałem ze znajomym Polakiem Władkiem, synem obywatela. Wręczyłem mu jeszcze $300 \mathrm{zł}$ dla Rubina i prosiłem go, żeby mi przyniósł odpowiedź. Po półgodzinie doszła do mnie kobieta, która wróciła ze sklepu niedaleko gminy, i mówi: panie Kopyto, dużo taksówek, dużo taksówek z Niemcami pojechało w kierunku Szczeglacina. Poczułem, że coś się stanie. Po pewnym czasie wrócił Władek, któremu dałem list dla Rubina Rozenberga. Powiedział mi, że ledwo zdążył [...] list przy bramie obozu, gdy nadjechali Niemcy na taksówkach, zaatakowali Żydów w Szczeglacinie. Władek, słysząc jęk i strzały, ukrył się pod szeroką sosną w gaju i wszystko obserwował. Była godzina 9-9.30. Widział, jak drągami bili Żydów, jak kazali im kopać doły. Potem zobaczył, że Niemcy odjeżdżają. Chciał wiedzieć, co się stało. Podjechał na rowerze od strony dołu. Widział, że ziemia się ruszała, ale Żydów już nie widział. Stało się to około 22 października 1942 roku. Dowiedziałem się od innych Polaków, że Szczeglacin został wykończony. Było tam 800 Żydów, przeważnie z Sokołowa. Dowiedziawszy się o tym, chodziłem zupełnie nieprzytomny"15.

\section{Żydzi, którzy pomiędzy chłopami mieszkali}

Skoro - zgodnie z tym, co twierdzą świadkowie, a także zeznaje Kopyto - w obozie w Szczeglacinie byli ulokowani Żydzi niemiejscowi, rodzi się pytanie, co się stało z tutejszymi Żydami, których przed wojną, w 1921 r. było, zgodnie ze spisem ludności w gminie Korczew, 191 (wyznania mojżeszowego było natomiast 213 osób). Według relacji mieszkańców tutejsi Żydzi w większości, jeśli nie uciekli za Bug do Sowietów lub nie ukryli się w lasach, czasem u Polaków, byli rozstrzeliwani na miejscu. Jako przykład może tu posłużyć opowieść Mieczysława Łoniewskiego z Korczewa:

\footnotetext{
${ }^{13}$ Ibidem, s. 33.

${ }^{14}$ Ibidem, s. 34.

${ }^{15}$ Ibidem, s. 39-40.
} 
„Ja to jeszcze łebek byłem... Tylko widziałem, jak Żydów gnali w Korczewie. Czterech zabili Niemcy na wzgórku. W Korczewie było czterech Żydów w czworakach. Pochowali się po piecach chlebowych, a ktoś ich oskarżył, wydał i gnali ich przez las Niemcy. A W. L., ten Lucia brat, gonił za tymi Żydami, by się Niemcom chwalić, że Żydów łapie, i go postrzelili, ma szczęście, że go nie zabili. Tu jak pobili na górce, to jeszcze J. M., szmaciarzem takim był, to później złote zęby im powybijał kamieniami, butów, oficerek nie dało mu się ściągnąć, to siekierą odrąbał nogi.

A przed wojną to sporo Żydów mieszkało. Takie o, to krawce, to szewce, to handlarzyki" 16 .

Florian Roszuk, chłop z Bartkowa Nowego, przez lata pisał pamiętniki czy też raczej spisywał dzieje swych okolic. W zapiskach przechowywanych przez rodzinę zmarłego w latach osiemdziesiątych XX w. kronikarza zawartych jest kilka wzmianek o tamtejszych Żydach, które w jakiś sposób naświetlają ich relacje z polskimi chłopami oraz hrabiami z Korczewa. Z uwagi na temat niniejszej pracy interesująca jest ostatnia wzmianka Floriana Roszuka dotycząca Żydów: „Potem Żydów zgonili do getta, każdy Jude miał opaskę na rękawie z gwiazdą Dawida. Wozili i gnali na piechotę do Treblinki, tam był koniec wszelkich gisewtuw"17.

Swoisty element oceny w tej wzmiance brzmi bardzo źle, przy czym zastanawia czy wręcz szokuje to, że ten skrupulatny kronikarz lokalny ani słowem nie wspomina o regulowaniu przez robotników żydowskich płynącej nieopodal jego domu Kołodziejki czy o masakrze w Szczeglacinie. Stereotypowo i dość enigmatycznie informuje tylko o Treblince, miejscu, gdzie nastąpił „koniec wszelkich gisewtuw”.

\section{Wzmianki w publikacjach regionalnych}

W Ziemi korczewskiej, publikacji powstałej we współpracy m.in. ze Zbigniewem Chybowskim, autor Adam Buszko jedynie wspomina o obozie pracy w Szczeglacinie: „W 1942 roku między Szczeglacinem a Mogielnicą istniał obóz pracy dla 800-osobowej grupy ludności żydowskiej z okolicznych miejscowości. Część tej grupy zmarła podczas ciężkich prac melioracyjnych. Pozostałych około 400 Niemcy wymordowali jesienią 1942 roku. Ciała pomordowanych wywieziono w nieznanym kierunku. Niektórzy świadkowie twierdzili, że do wykopanych dołów w Cerkwisku oprawcy wrzucali prawdopodobnie żyjących jeszcze ludzi”18. Brakuje tu podstawowych informacji dotyczących zbrodni, przede wszystkim jednak zwraca uwagę faktograficzny błąd. Masakra miała przecież miejsce w Szczeglacinie, a nie w Cerkwisku, które było siedzibą wcześniejszego obozu. Doły, do których wrzucano „prawdopodobnie żyjących jeszcze ludzi”, wykopane zostały nie w Cerkwisku, a w Szczeglacinie.

\footnotetext{
${ }^{16}$ M. Łoniewski, Korczew, ur. 1936, rozmowa z autorką z dn. 2 VIII 2009 r.

${ }^{17}$ F. Roszuk, pamiętnik (rękopis), Bartków Stary, 1978 r.

${ }^{18}$ A. Buszko, Ziemia korczewska, Korczew 1997, s. 37.
} 
W książce Nadbużańskim szlakiem. Od Korczewa do Treblinki napisano jedynie, że ,już na przełomie roku 1940/41 zostały wprowadzone ograniczenia terenowe dla ludności tych terenów, a następnie powstają getta na terenie Sokołowa, Kosowa Lackiego i Sterdyni oraz przejściowy obóz w Szczeglacinie koło Korczewa. Pierwszą likwidację tych gett przeprowadzili Niemcy 30 września 1942 roku, drugą wiosną roku 1943”19. Bardzo zwięzła i niewiele mówiąca notka.

Więcej informacji na temat okolicznych Żydów, w tym ich prac przy regulacji Kołodziejki, znajdziemy w książce Zbigniewa Florysiaka Korczew lat okupacji niemieckiej. Okruchy wspomnień. Florysiak pisze, że już w 1940 r. przystąpiono do regulacji rzeki, a „powołane w Sokołowie specjalne biuro ogłosiło przetarg wygrany przez Przedsiębiorstwo Robót Inżynieryjnych inż. Jerzego Marynowskiego z Warszawy”. Sołtysi byli zobowiązani zapewniać codziennie odpowiednią ilość robotników, ale ponieważ było to bardzo źle płatne (59 gr za godzinę pracy od świtu do nocy), miejscowi uchylali się od tego na wszelkie sposoby. Starosta niemiecki Grass groził karami i określał Korczew, według Florysiaka, mianem „najkrnąbrniejszej wsi”. „Potem do prac melioracyjnych zatrudniono Żydów przywiezionych $\mathrm{z}$ gett $\mathrm{w}$ pobliskich miastach i zakwaterowano w barakach na Cerkwisku i w Szczeglacinie"20.

Zbigniew Chybowski natomiast opublikował w „Tygodniku Siedleckim” artykuł o obozie w Szczeglacinie zainspirowany zdarzeniem będącym reinterpretacją wątku lokalnej zagłady. Otóż uczennica ze szkoły podstawowej w Korczewie przyniosła mu w 1993 r. na lekcję historii menażkę wojskową z wyrytą gwiazdą Dawida. Chybowski napisał wówczas, że „została znaleziona na terenie "getta« w Szczeglacinie i stanowi obecnie jeden $z$ nielicznych dowodów niemieckiego ludobójstwa na co najmniej kilkuset obywatelach Polski narodowości żydowskiej wymordowanych jesienią 1942 r."21 Po pewnym czasie okazało się, że dziewczynka, usłyszawszy o szczeglacińskim obozie pracy, sama wyryła symbol na menażce, niemniej - szczęście w nieszczęściu - historyk zainteresował się w konsekwencji tym tematem, czego efektem była m.in. rozmowa przeprowadzona ze Szczepaniakiem.

\section{Epilog}

Przedstawione tu źródła są niejednorodne - od relacji ustnych, zbieranych przeze mnie w 2009 r. w okolicznych wsiach oraz w samym Szczeglacinie, poprzez zapisy sporządzone w 1947 r. (Kopyto) i 1994 r. (Szczepaniak), po rękopis pamiętnika Roszuka i publikacje regionalne.

Te źródła zarysowują wciąż nie do końca jasny obraz szczeglacińskich wydarzeń. Zadanie, by zebrać jak najwięcej informacji, ustalić fakty i powiązać je w spój-

${ }^{19}$ Nadbużańskim szlakiem. Od Korczewa do Treblinki, red. W. Piecyk, W. Wierzchowska, Sokołów Podlaski 1999, s. 42.

${ }^{20}$ Z. Florysiak, Korczew lat okupacji niemieckiej. Okruchy wspomnień, Siedlce 2009, s. 41.

${ }^{21}$ Z. Chybowski, Menażka z gwiazdą Dawida, „Tygodnik Siedlecki”, 12 VI 1994, nr 24, s. 7. 
ny ciąg, okazało się niełatwe, gdyż nie wszyscy mieszkańcy gminy Korczew wiedzą, co działo się tu z Żydami, a i świadkowie wydarzeń, które miały miejsce przed sześćdziesięcioma ośmioma laty, nie pamiętają oczywiście wszystkiego szczegółowo. Pamięć ludzka rządzi się takimi prawami, że z czasem wątki się mieszają i tracą ciąłłość, a obraz historii zmienia się w czasie wraz z osobą jej narratora. Słowa świadków wspominających dziś epizod z Zagłady nierzadko dają obraz nie tyle traumatycznego wydarzenia, ile jego racjonalizacji.

Każda z opowiedzianych mi historii jest inna - subiektywna, zależna od okoliczności powstawania przekazu, często różniąca się co do meritum od pozostałych. W relacjach interesowały mnie zarówno historyczne fakty, o których opowiadali moi rozmówcy, jak i przydawane im przez nich znaczenia i sensy. „Głównym celem historii mówionej nie jest odkrywanie nieznanych faktów. Pamięć nie jest bowiem depozytariuszem faktów, lecz aktywnym procesem nadawania znaczeń”22. Wartość i znaczenie takich relacji wiąże się z subiektywizmem przekazu i interpretacji, samorzutnością i wielogłosowością. Polifonia oral history nie wyklucza jednak możliwości wyłonienia się podstawowej linii melodycznej, gdy część wspólna historii zacznie się klarować.

Świadkowie wydarzeń odchodzą. Upamiętnienia brakuje - ani w Cerkwisku, ani w Szczeglacinie nie postarano się o jakikolwiek znak przywołujący wspomnienie dokonanej w przeszłości zbrodni.

Znakiem niewolniczej pracy i zagłady Żydów mogłaby być wyregulowana niemal do linii prostej Kołodziejka, ale i sama rzeka zmieniła swoje oblicze przez siedemdziesiąt już prawie lat. Teraz inni inżynierowie zmieniają jej bieg - są to bobry. Życie toczy się dalej, woda płynie, jak zawsze, w stronę Bugu.

\title{
Słowa kluczowe
}

Zagłada Żydów, obóz pracy w Szczeglacinie

\begin{abstract}
The article deals with a labor camp for Jews founded by the Germans in Cerkwisko near Bartków Nowy, Karczew Commune, was transferred to the village of Szczeglacin due to the works' extension along the river. The Jews who died in that camp performed work connected with water management which consisted of farmland draining and engineering on Kołodziejka, a tributary of Bug river. The liquidation of the Szczeglacin camp took place probably in the morning of 22 October 1942. Several hundred Jews were killed with a primitive tool - a wooden club. According to the witnesses, "when spring came," likely in 1944, the Germans returned to the spot to conduct an exhumation of the remains in order to ultimately cover the traces. The article is based on various sources - from oral accounts, collected in 2009 in Szczeglacin and the neighboring villages, through records produced in 1947 (Josek
\end{abstract}

\footnotetext{
${ }^{22}$ P. Filipkowski, Historia mówiona i wojna, Warszawa 2005, s. 5.
} 
$192 \quad$ Z warsztatów badawczych

Kopyto's testimony) and 1994 manuscript of a peasant from Bartków Stary as well as regional publications.

\section{Key words}

Holocaust, the labor camp in Szczeglacin 